\section{Steel Slag Raises pH of Greenhouse Substrates}

\author{
James E. Altland \\ USDA-ARS, Application Technology Research Unit, 27 Horticultural Insects \\ Research Laboratory, 1680 Madison Avenue, Wooster, OH 44691
}

James C. Locke', Wendy L. Zellner, and Jennifer K. Boldt

USDA-ARS, Application Technology Research Unit, Greenhouse Production

Research Group, 2801 West Bancroft Street, Mail Stop 604, Toledo, OH 43606

Additional index words. dolomitic lime, sunflower, peatmoss, floriculture, electrical conductivity

\begin{abstract}
Dolomitic lime (DL) is the primary liming agent used for increasing $\mathrm{pH}$ in peatmoss-based substrates. Steel slag (SS) is a byproduct of the steel manufacturing industry that has been used to elevate field soil $\mathrm{pH}$. The objective of this research was to determine the $\mathrm{pH}$ response of a peatmoss-based greenhouse substrate to varying rates of DL or SS. Two experiments were conducted with an 85 peatmoss : 15 perlite substrate. In the first experiment, the substrate was amended with $0,2.4,4.8$, or $7.1 \mathrm{~kg} \cdot \mathrm{m}^{-3}$ of either DL or SS. Half of the containers remained fallow and the other half were potted with a single sunflower (Helianthus annuus L. 'Pacino Gold'). In the second experiment, fallow containers were only used with the substrate amended with $0,2.4,4.8,9.5$, or 14.2 $\mathrm{kg} \cdot \mathrm{m}^{-3}$ DL or SS. Sunflower were measured for relative foliar chlorophyll content, shoot mass, root ratings, and foliar nutrient concentrations. Substrate electrical conductivity (EC) and pH were measured weekly using the pour-through procedure. All sunflower plants grew vigorously, although nonamended controls had less shoot dry weight than those amended with DL or SS. There were minor differences in foliar concentration of $N$, $\mathrm{Ca}, \mathrm{Mg}$, and Mn; however, these differences did not adversely affect plant growth. Summarizing across both experiments, EC was affected by treatment and time, although all substrates had $\mathrm{EC}$ readings within the range recommended for floriculture crop production (1.0-4.6 $\left.\mathrm{mS} \cdot \mathrm{cm}^{-1}\right)$. Substrate $\mathrm{pH}$ differed slightly in Expt. 1 between fallow and planted containers. Substrate $\mathrm{pH}$ increased exponentially with increasing rates of either DL or SS. Maximum pH in fallow DL and SS amended substrates was 6.57 and 6.93, respectively, in Expt. 1 and 6.85 and 7.67, respectively, in Expt. 2. The SS used in this experiment resulted in a greater $\mathrm{pH}$ response than $\mathrm{DL}$ with higher application rates. $\mathrm{SS}$ is a viable material for raising $\mathrm{pH}$ of soilless substrates.
\end{abstract}

The primary component in greenhouse potting substrates is sphagnum peatmoss. Substrate solution $\mathrm{pH}$ of nonamended peatmoss ranges from 4.0 to 4.5 (Landis, 1990). Optimum substrate $\mathrm{pH}$ has been determined for economically important crops such as zonal and ivy geranium (Pelargonium ×hortorum L.H. Bailey and P. peltatum (L.) L'Hér. ex Aiton, respectively) (Andrews and Hammer, 2006), petunia (Petunia $\times$ hybrida (Sweet) D. Don ex W. H. Baxter), impatiens (Impatiens walleriana Hook.f.) (Smith et al., 2004), and poinsettia (Euphorbia pulcherrima Willd. ex Klotzsch) (Bateman, 1962). Ideal $\mathrm{pH}$ for most greenhouse floriculture crops ranges from 5.8 to 6.2 (Argo and Fisher, 2002). DL $\left[\mathrm{CaMg}\left(\mathrm{CO}_{3}\right)\right]$ is often used to elevate substrate $\mathrm{pH}$ in peatmoss-based media

Received for publication 3 Sept. 2014. Accepted for publication 14 Oct. 2014.

Mention of proprietary products or private companies is included for the reader's convenience and does not imply any endorsement or preferential treatment by USDA-ARS.

${ }^{1}$ To whom reprint requests should be addressed; e-mail jim.locke@ars.usda.gov.
(Raviv and Lieth, 2008). Sphagnum peatmoss contains 1 to $2 \mathrm{mg} \cdot \mathrm{L}^{-1}$ plant-available calcium (Ca) and magnesium (Mg) (Landis, 1990), whereas standards for container culture recommend 80 and $30 \mathrm{mg} \cdot \mathrm{L}^{-1} \mathrm{Ca}$ and $\mathrm{Mg}$, of $\mathrm{Ca}$ and $\mathrm{Mg}$, and generally in the correct ratio (although the ratio varies by lime source) (Handreck and Black, 2002), DL is often preferred over calcitic limestone $\left(\mathrm{CaCO}_{3}\right)$ which contains primarily calcium carbonate.

SS is a byproduct of the steel industry, with potential as a liming agent for greenhouse substrates. As steel scraps and iron ore are melted in a basic oxygen furnace, calcium oxide $(\mathrm{CaO})$ and $\mathrm{DL}$ are introduced as fluxing agents to remove impurities from the molten steel. Mineral impurities removed by the fluxing agents, along with the $\mathrm{CaO}$ and $\mathrm{DL}$, form a molten slag. The slag is poured off from the steel, cooled, and processed into particle size fractions ranging from dust to gravel. Rodriguez et al. (1994) demonstrated increased soil $\mathrm{pH}$ and yield of perennial ryegrass (Lolium perenne L.), cocksfoot (Dactylis glomerata L.), and white clover (Trifolium pastures. Likewise, Ali and Shahram (2007) respectively. Because DL contains carbonates repens L.) following applications of SS on showed SS elevated $\mathrm{pH}$ of acidic soils and increased corn (Zea mays L.) shoot dry mass.

Properties of SS vary not only by the type of furnace in which steel is produced, but also within a particular furnace type (Yildirim and Prezzi, 2011). Despite differences, most SS are similar in that they are composed primarily of $\mathrm{CaO}, \mathrm{SiO}_{2}$, and $\mathrm{FeO}$, with $\mathrm{CaO}$ making up more than $35 \%$ of SS mass (Yildirim and Prezzi, 2011). Pure $\mathrm{CaO}$ is a known liming agent with a relatively high calcium carbonate equivalency (CCE, 179\%) compared with DL (109\%), calcitic lime (100\%), or hydrated lime (136\%) (Peters et al., 1996). CaO, also known as quicklime or burnt lime, is commonly used in cement and road construction, but rarely used in its pure form as a liming agent in agriculture due to its hydroscopic and caustic properties. Mayfield et al. (2002) demonstrated that $\mathrm{CaO}$ served as a suitable alternative to DL for the production of container-grown heavenly bamboo (Nandina domestica Thunb. 'Nana purpurea'). No additional research could be found that addressed the use of $\mathrm{SS}$ or $\mathrm{CaO}$ as a liming agent in soilless substrates. The objective of this research was to quantify and model the impact of $\mathrm{SS}$ on $\mathrm{pH}$ of a peatmoss-based greenhouse substrate, and compare SS to the industry standard DL.

\section{Materials and Methods}

General conditions. Sunflower [Helianthus annuus L. 'Pacino Gold' (Ball Seed, West Chicago, IL)] were sown in a 288-cell flat filled with Sunshine Mix No. 2 (Sun Gro Horticulture, Seba Beach, Alberta, Canada) on 17 Oct. 2013 and transplanted 7 Nov. 2013. Peatmoss (Sun Gro Horticulture) and medium grade coarse perlite (Sun Gro Horticulture) were mixed by hand to create an 85 peatmoss : 15 perlite (v:v) blend. The DL (ECOPHRST, National Lime and Stone Co., Findlay, $\mathrm{OH}$ ) contained $52.4 \% \mathrm{CaCO}_{3}$ and $41.6 \% \mathrm{MgCO}_{3}$, had $103 \% \mathrm{CCE}$ and $100 \%$ of material passing through 100 mesh sieve. The SS (Edward C. Levy Co., Dearborn, MI) contained $38.4 \% \mathrm{CaO}, 29.5 \% \mathrm{FeO}, 13.3 \%$ $\mathrm{SiO}_{2}, 8.5 \% \mathrm{MgO}, 3.8 \% \mathrm{Al}_{2} \mathrm{O}_{3}$, and 3.4\% $\mathrm{MnO}$, had $73 \% \mathrm{CCE}$ with $27 \%$ passing through a 100-mesh sieve.

Expt. 1. The substrate was amended with $0,2.4,4.8$, or $7.1 \mathrm{~kg} \cdot \mathrm{m}^{-3}$ of either SS or DL. Each amended substrate was filled into 10 containers of $10-\mathrm{cm}$ diameter $\left(\approx 600-\mathrm{cm}^{3}\right.$ volume). Half of the containers were potted with a sunflower plug and half remained fallow. A 15 -cm-diameter clear vinyl saucer (Hummert Intl., Earth City, MO) was placed beneath each container to capture a leachate and allow it to be reabsorbed by the substrate. Containers were irrigated as needed and fertilized at each irrigation event with a commercial complete fertilizer providing micronutrients (Jack's $20 \mathrm{~N}-4.4 \mathrm{P}-16.6 \mathrm{~K}-0.15 \mathrm{Mg}-$ $0.02 \mathrm{~B}-0.01 \mathrm{Cu}-0.1 \mathrm{Fe}-0.05 \mathrm{Mn}-0.01 \mathrm{Mo}-$ $0.05 Z n$ ) (JR Peters, Inc., Allentown, PA) at a rate of $100 \mathrm{mg} \cdot \mathrm{L}^{-1}$ nitrogen $(\mathrm{N})$. Initially, fallow and planted containers were irrigated similarly, about four times per week, with 
$100 \mathrm{~mL}$ per irrigation event. Gradually, planted containers required greater irrigation volume, up to $200 \mathrm{~mL}$ per irrigation event. Containers were arranged in a completely randomized design on a bench in a glasscovered greenhouse in Wooster, OH. The glasshouse was maintained with heat and cool setpoints of 18 and $24{ }^{\circ} \mathrm{C}$, respectively. Natural light was supplemented with high pressure sodium vapor lights for 13 hours daily from 6 AM to 7 PM.

Containers were subjected to the pourthrough technique (Wright, 1986) weekly to collect a $50-\mathrm{mL}$ sample of the substrate solution for the measurement of $\mathrm{pH}$ and $\mathrm{EC}$. Relative chlorophyll content was determined weekly on sunflowers with a chlorophyll meter (Minolta-502 SPAD meter; Spectrum Technologies, Inc., Plainfield, IL) by taking a measurement on five leaves per container and recording the mean. At the conclusion of the experiment, 6 weeks after potting (WAP), recently matured sunflower foliage was harvested for foliar nutrient analysis (Mills and Jones, 1996), rinsed with deionized water, then oven dried at $55{ }^{\circ} \mathrm{C}$ for $3 \mathrm{~d}$. Samples were ground in a mill (Tecator Cyclotec AB, Hogenas, Sweden) through a $0.5-\mathrm{mm}$ screen. Foliar $\mathrm{N}$ was determined with a nitrogen analyzer (PerkinElmer Series II CHNS/O Analyzer; PerkinElmer Instruments, Shelton, $\mathrm{CT}$ ). Other macronutrients and micronutrients were determined with optical emission spectroscopy (iCAP 6000 Spectrophotometer; Thermo Fisher Scientific, Waltham, MA). Shoot dry weight (SDW) of each crop was determined by removing the shoot portion of the plant, oven drying at $55^{\circ} \mathrm{C}$ for $3 \mathrm{~d}$, and weighing. Sunflower roots visibly growing along the root ball-container interface were subjectively rated on a scale from 0 to 5 where $0=$ no roots visible and $5=100 \%$ of the interface covered by white, healthy roots.

Expt. 2. The previous experiment was repeated 6 Mar. 2014 with the following exceptions. DL and SS were amended at rates of $0,2.4,4.8,9.5$, or $14.2 \mathrm{~kg} \cdot \mathrm{m}^{-3}$. The experiment was conducted in fallow containers only with six replications per amendment and rate. The pour-through procedure was used to collect leachate samples on 1, 2, 4, and 8 WAP.

$\mathrm{EC}$, substrate $\mathrm{pH}$, and SPAD were subjected to repeated measures of analysis of variance (ANOVA) by using the "repeated" option in the general linear model (GLM) procedure of SAS v9.3 (SAS Institute Inc., Cary, NC). Sunflower SDW and foliar nutrient data were subjected to ANOVA using the GLM procedure. Fisher's protected least significant difference was used to compare treatment means. Substrate $\mathrm{pH}$ response to amendment rate were fit to exponential curves $\left(\mathrm{pH}=\mathrm{a}+\mathrm{b} \cdot\left(1-\mathrm{e}^{-\mathrm{cx}}\right)\right.$ were $x=$ amendment rate, $a$ is the predicted $\mathrm{pH}$ when $x=0$, the sum $a+b$ is the maximum extrapolated $\mathrm{pH}$ as $x$ approaches infinity, and $c$ is a scaling parameter. Nonlinear models were fit using the "NLIN" procedure in SAS. Fitted parameters were compared using the sums of squares reduction (SSR) test (Schabenberger and Pierce, 2002), in which $P$ values were generated to test the hypothesis that the fitted equations were similar. All statistical analyses were conducted with SAS v.9.3, whereas exponential functions were plotted with SigmaPlot v.12 (Systat Software, Inc., San Jose, CA).

\section{Results and Discussion}

Repeated measures indicated a significant time by treatment interaction for EC $(P<$ $0.0001)$. EC changed over time, but there were few and minor differences among treatments each week (Table 1). Treatment effects were only significant on weeks 3 and $4(P=$ 0.0289 and 0.0029 , respectively), but even then there were no consistent or discernible pattern for main effects on EC. Substrate EC was higher in containers without a plant compared with those with a plant only at 4 WAP (3.2 vs. $\left.2.6 \mathrm{mS} \cdot \mathrm{cm}^{-1}\right)$. Averaging across all amendments and rates, substrate EC was initially $2.1 \mathrm{mS} \cdot \mathrm{cm}^{-1}$ on week 1 , increased to $2.9 \mathrm{mS} \cdot \mathrm{cm}^{-1}$ on week 4 , and declined to 2.4 by week 6 . Substrate EC was measured on containers irrigated with a fertilizer solution and not leached (via use of plastic saucers placed beneath the container). The impact of the water-soluble fertilizer used with each irrigation might have masked any effect from amendments. These levels are within the recommended range of EC readings $\left(1.0-4.6 \mathrm{mS} \cdot \mathrm{cm}^{-1}\right)$ for floriculture crops by using the pour-through technique (Cavins et al., 2000).

With respect to substrate $\mathrm{pH}$, repeated measures revealed time interacted with amendment type, rate within an amendment, and the presence or absence of a plant in the container $(P<0.0001)$. Despite repeated measures indicating a change in $\mathrm{pH}$ over time, absolute change in $\mathrm{pH}$ within a treatment, relative to that measured $1 \mathrm{WAP}$, did not exceed $0.5 \mathrm{pH}$ units throughout the experiment (except the fallow control at 6 WAP). Amendment type (DL or SS) and rate within an amendment type were significant main effects throughout the experiment, as expected (Table 2). The presence or absence of a plant did not affect the substrate $\mathrm{pH}$ at 1 WAP $(P=0.5492)$, although, the main effect or its interaction with amendment type and/or rate did affect substrate $\mathrm{pH}$ throughout the remainder of the experiment. Across the experiment, the maximum $\mathrm{pH}$ difference between fallow and planted containers was $0.43 \mathrm{pH}$ units at week 3 with the lowest SS rate, and the average difference in fallow and planted containers was $0.10 \mathrm{pH}$ units higher in fallow containers.

At 1 WAP, the SSR test also showed $\mathrm{pH}$ in containers with or without a plant were similar $(P=0.9748$; Fig. 1$)$, which corroborates the ANOVA results. This is not surprising, as the root system from a recently potted 288-cell plug would not likely be large enough to influence the bulk substrate solution. Pooling over fallow and planted containers, substrate $\mathrm{pH}$ in DL-amended containers increased exponentially with increasing rate from 4.49 at $0 \mathrm{~kg} \cdot \mathrm{m}^{-3}$ up to 6.51 at the highest amendment rate. Assuming the exponential curve is an accurate model of the

Table 1. Electrical conductivity of an 85 peatmoss : 15 perlite substrate amended with three rates of either dolomitic lime (DL) or steel slag (SS), in either containers that were either fallow or planted with a single sunflower (Helianthus annuus 'Pacino Gold') plant, Expt. $1(n=5)$.

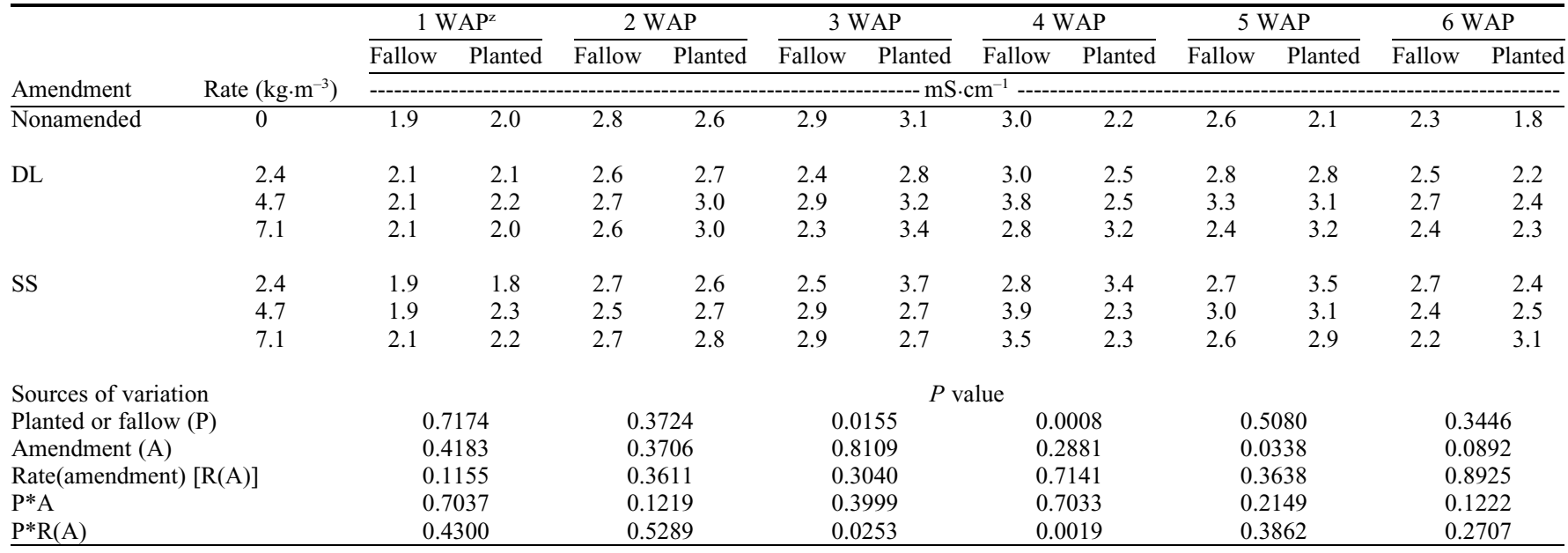

${ }^{\mathrm{z}}$ Weeks after potting (WAP), 17 Oct. 2013 
Table 2. Substrate $\mathrm{pH}$ of a 85 peatmoss : 15 perlite substrate amended with three rates of either dolomitic lime (DL) or steel slag (SS), in containers that were either fallow or planted with a single sunflower (Helianthus annuus 'Pacino Gold') plant, Expt. $1(n=5)$.

\begin{tabular}{|c|c|c|c|c|c|c|c|c|c|c|c|c|c|}
\hline \multirow[b]{2}{*}{ Amendment } & \multirow[b]{2}{*}{ Rate $\left(\mathrm{kg} \cdot \mathrm{m}^{-3}\right)$} & \multicolumn{2}{|c|}{$1 \mathrm{WAP}^{\mathrm{z}}$} & \multicolumn{2}{|c|}{2 WAP } & \multicolumn{2}{|c|}{3 WAP } & \multicolumn{2}{|c|}{4 WAP } & \multicolumn{2}{|c|}{5 WAP } & \multicolumn{2}{|c|}{$6 \mathrm{WAP}$} \\
\hline & & Fallow & $\overline{\text { Planted }}$ & Fallow & $\overline{\text { Planted }}$ & Fallow & $\overline{\text { Planted }}$ & Fallow & $\overline{\text { Planted }}$ & Fallow & $\overline{\text { Planted }}$ & Fallow & Planted \\
\hline Nonamended & 0 & 4.49 & 4.46 & 4.67 & 4.58 & 4.77 & 4.55 & 4.89 & 4.79 & 4.94 & 4.57 & 5.07 & 4.56 \\
\hline \multirow[t]{3}{*}{$\mathrm{DL}$} & 2.4 & 5.92 & 5.90 & 5.99 & 5.90 & 6.12 & 5.82 & 5.92 & 5.87 & 5.88 & 5.79 & 5.76 & 5.81 \\
\hline & 4.7 & 6.31 & 6.29 & 6.31 & 6.21 & 6.34 & 6.13 & 6.05 & 6.28 & 6.22 & 6.26 & 6.21 & 6.26 \\
\hline & 7.1 & 6.51 & 6.53 & 6.47 & 6.36 & 6.56 & 6.23 & 6.42 & 6.35 & 6.56 & 6.40 & 6.57 & 6.36 \\
\hline \multirow[t]{3}{*}{ SS } & 2.4 & 5.47 & 5.48 & 5.67 & 5.55 & 5.83 & 5.41 & 5.80 & 5.44 & 5.57 & 5.36 & 5.41 & 5.38 \\
\hline & 4.7 & 6.49 & 6.44 & 6.52 & 6.45 & 6.44 & 6.27 & 6.07 & 6.37 & 6.27 & 6.29 & 6.19 & 6.34 \\
\hline & 7.1 & 6.95 & 6.95 & 6.98 & 6.82 & 6.77 & 6.63 & 6.65 & 6.76 & 6.84 & 6.70 & 6.93 & 6.65 \\
\hline \multicolumn{2}{|l|}{$\mathrm{LSD}_{0.05}$} & \multicolumn{2}{|c|}{0.12} & \multicolumn{2}{|c|}{0.08} & \multicolumn{2}{|c|}{0.14} & \multicolumn{2}{|c|}{0.17} & \multicolumn{2}{|c|}{0.17} & \multicolumn{2}{|c|}{0.19} \\
\hline \multicolumn{6}{|c|}{ Sources of variation } & \multicolumn{4}{|c|}{$P$ value } & & \\
\hline \multicolumn{2}{|c|}{ Planted or fallow (P) } & \multicolumn{2}{|c|}{0.5492} & \multicolumn{2}{|c|}{0.0001} & \multicolumn{2}{|c|}{0.0001} & \multicolumn{2}{|c|}{0.9080} & \multicolumn{2}{|c|}{0.0001} & \multicolumn{2}{|c|}{0.0001} \\
\hline \multicolumn{2}{|c|}{ Amendment (A) } & \multicolumn{2}{|c|}{0.0001} & \multicolumn{2}{|c|}{0.0001} & \multicolumn{2}{|c|}{0.0001} & \multicolumn{2}{|c|}{0.0001} & \multicolumn{2}{|c|}{0.0001} & & 01 \\
\hline Rate(amendm & {$[\mathrm{R}(\mathrm{A})]$} & 0.0 & 01 & 0.0 & & 0.0 & & 0.0 & 01 & & 01 & & 01 \\
\hline $\mathrm{P} * \mathrm{~A}$ & & 0.9 & 285 & 0.7 & & & & & 968 & & 85 & & 02 \\
\hline $\mathrm{P} * \mathrm{R}(\mathrm{A})$ & & 0.9 & 186 & 0.5 & 582 & 0.0 & & & 001 & & 713 & & 16 \\
\hline
\end{tabular}

${ }^{\mathrm{z}}$ Weeks after potting (WAP), 17 Oct. 2013.

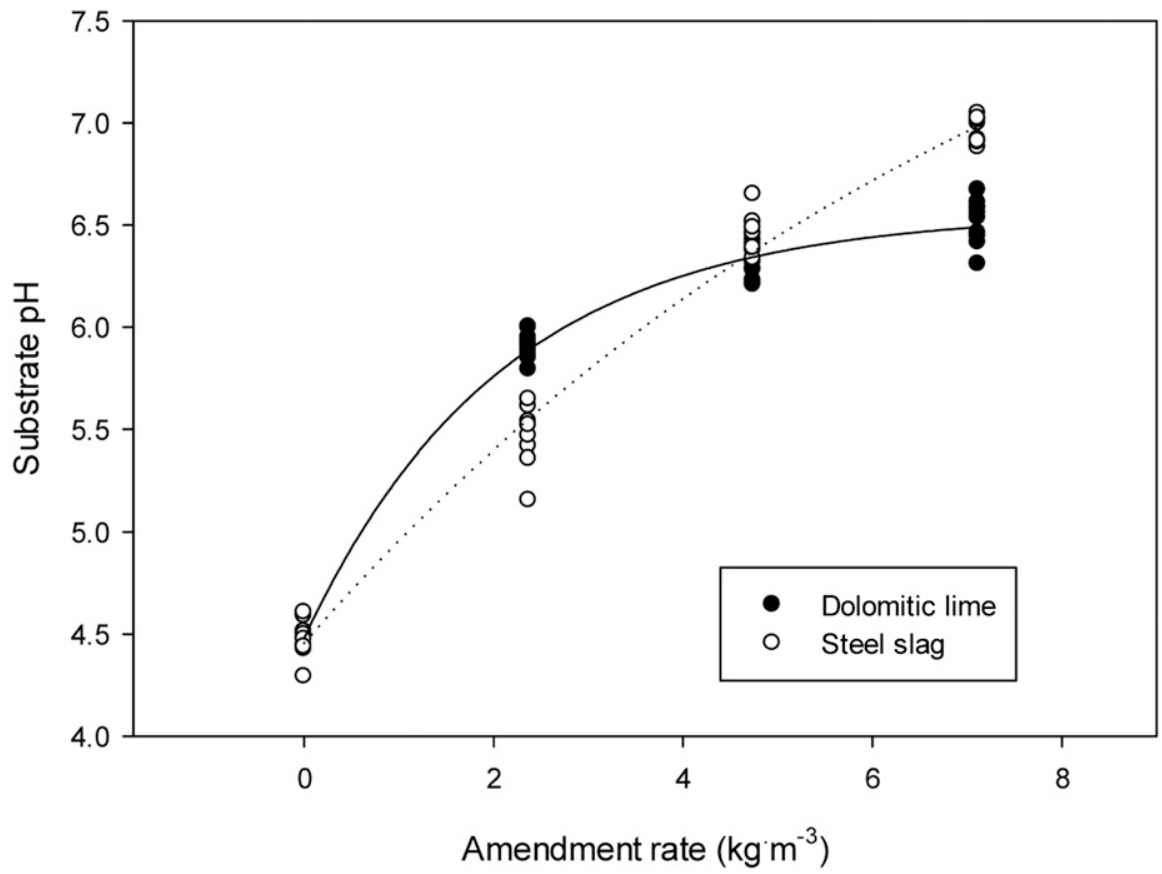

Fig. 1. Relationship between dolomitic lime (DL) or steel slag (SS) amendment rate and substrate $\mathrm{pH}$ at 1 week after potting in Ext. 1. Data were fit to the following exponential functions: $\mathrm{DL} \mathrm{pH}=4.48+2.08^{*}$ $\left(1-\mathrm{e}^{-0.48^{*} \mathrm{x}}\right), R^{2}=0.9887 ; \mathrm{SS} \mathrm{pH}=4.46+4.35^{*}\left(1-\mathrm{e}^{-0.12^{*} \mathrm{x}}\right), R^{2}=0.9860$.

relationship between $\mathrm{pH}$ and $\mathrm{DL}$ rate, the extrapolated maximum $\mathrm{pH}$ would be 6.56 (sum of fitted parameters $a$ and $b$ ), and thus the maximum extrapolated $\mathrm{pH}$ was achieved with the $7.1 \mathrm{~kg} \cdot \mathrm{m}^{-3}$ rate. In contrast, the SSamended substrate increased from 4.49 at $0 \mathrm{~kg} \cdot \mathrm{m}^{-3}$ up to 6.95 at $7.1 \mathrm{~kg} \cdot \mathrm{m}^{-3}$. The $\mathrm{pH}$ response to SS was also fit to an exponential curve, with an extrapolated maximum $\mathrm{pH}$ of 8.81. Our assumption is that the substrate response to SS is exponential, where it increases rapidly then plateaus with high rates. However, at rates applied in this experiment, the response over the range from 0 to 7.1 $\mathrm{kg} \cdot \mathrm{m}^{-3}$ was only slightly curvilinear with little indication of plateau.

By 6 WAP, pH response in containers with and without sunflower differed according to the SSR test $(P<0.0001$; Fig. 2$)$. Substrate $\mathrm{pH}$ response to DL rate, with and without plants, were fit to exponential functions. Judging by the plotted lines of the fitted functions, $\mathrm{pH}$ was consistently higher in containers without sunflower, although $\mathrm{pH}$ in the 2.4 and $4.7 \mathrm{~kg} \cdot \mathrm{m}^{-3}$ rates were similar by way of means separation (Table 2 ). The extrapolated maximum value for DL-amended substrates was 6.77 in fallow containers and 6.50 with sunflower.

Substrate $\mathrm{pH}$ response to SS were initially fit to exponential curves, however, because of the lack of convergence in the nonlinear fitting routine for the SS-amended containers with no sunflower, the curve was fit with a simpler linear function (Fig. 2B). Similar to DL-amended substrates, SS-amended sub- strates had higher $\mathrm{pH}$ in containers without a sunflower compared with those with a sunflower. Likewise, the fitted curve for $\mathrm{pH}$ in fallow containers plotted consistently higher than those with a sunflower. Contrast analyses show that $\mathrm{pH}$ was higher in containers without sunflowers when amended with 2.4 $\mathrm{kg} \cdot \mathrm{m}^{-3}(P=0.0147)$, but similar at all other rates $(P>0.1180)$. Others have shown that the plant species can affect substrate $\mathrm{pH}$ (Smith et al., 2004), often lowering $\mathrm{pH}$ by increased $\mathrm{H}^{+}$extrusion (Marschner et al., 1986). Similar to 1 WAP data, $\mathrm{pH}$ in SSamended substrates increased rapidly with no indication of the typical $\mathrm{pH}$ plateau with lime amendments (Altland and Buamscha, 2008).

Foliar SPAD readings for sunflower changed over time $(P<0.0001$, data not shown), however there was no interaction between treatment effects and time $(P=$ 0.3727). Within each date, all sunflower had similar SPAD chlorophyll readings regardless of amendment or amendment rate $(P>$ 0.2768 ). Averaging across all treatments, foliar SPAD were initially 46.0 (a unitless measurement), increased up to 50.5 by week 3 , and declined to 45.3 by week 6 . Sunflower roots appeared healthy and vigorous in all treatments. All roots were white with no discoloration. Neither amendment type, nor rate affected root ratings (Table 3 ). Shoot dry mass was affected by an amendment type, but not the rate. Averaging across rates, sunflower in the nonamended controls, DL, and SS amended substrates had shoot dry mass of 6.0, 7.0, and $7.1 \mathrm{~g}$, respectively. Sunflower amended with DL and SL were similar in shoot dry weight, and both groups had more mass than nonamended controls. Despite differences in shoot mass, all plants appeared vigorous and healthy, with differences in growth difficult to discern by visual observation.

Tissue concentrations of $\mathrm{P}, \mathrm{K}, \mathrm{S}, \mathrm{B}, \mathrm{Fe}$, and $\mathrm{Zn}$ were unaffected by treatment (Table 4). Foliar $\mathrm{N}$ was affected by an amendment type $(P=0.0141)$, but not the rate within amendment $(P=0.1912)$. Averaging across rates, foliar $\mathrm{N}$ was higher in nonamended 

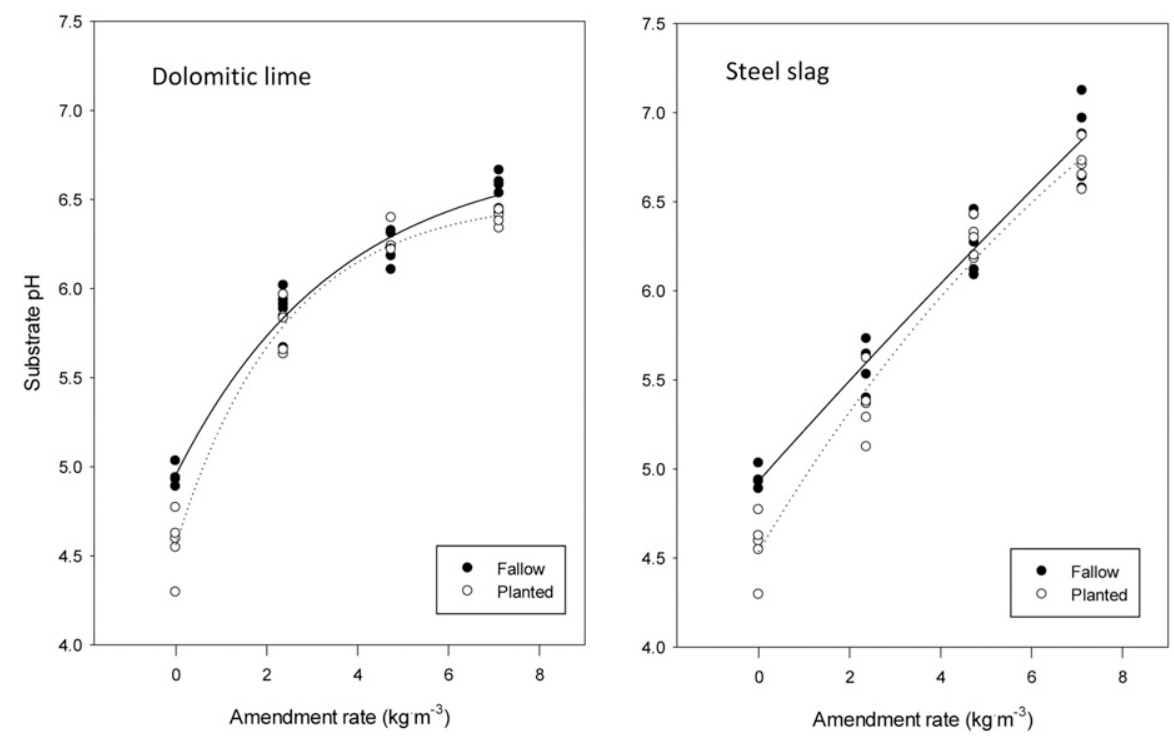

Fig. 2. Substrate $\mathrm{pH} 6$ weeks after potting (WAP) in a 85 peatmoss : 15 perlite substrate amended with 0 , $2.4,4.8$, or $7.1 \mathrm{~kg} \cdot \mathrm{m}^{-3}$ of dolomitic lime (DL) (A) or steel slag (SS) (B) in Expt. 1. At each amendment rate, half of the containers were fallow while the other half were planted with a sunflower (Helianthus annuus 'Pacino Gold'). Data for DL were fit to the following exponential functions: fallow $\mathrm{pH}=4.95+$ $1.82 *\left(1-\mathrm{e}^{-0.28^{*} \mathrm{x}}\right), R^{2}=0.9747$; planted $\mathrm{pH}=4.56+1.94 *\left(1-\mathrm{e}^{-0.42^{*} \mathrm{x}}\right), R^{2}=0.9783$. Data for SS were fit to either a simple linear equation (fallow) or exponential equation (planted): fallow $\mathrm{pH}=4.95+0.27 \mathrm{x}$, $R^{2}=0.9307 ;$ planted $\mathrm{pH}=4.54+4.40 *\left(1-\mathrm{e}^{-0.10^{*} \mathrm{x}}\right), R^{2}=0.9673$.

Table 3. Root rating and shoot dry weight of sunflower (Helianthus annuus 'Pacino Gold') growing in 85 peatmoss : 15 perlite substrate amended with dolomitic lime (DL) or steel slag (SS) at three rates, Expt. $1(n=5)$.

\begin{tabular}{lccc}
\hline Amendment & $\begin{array}{c}\text { Rate } \\
\left(\mathrm{kg} \cdot \mathrm{m}^{-3}\right)\end{array}$ & $\begin{array}{c}\text { Root } \\
\text { rating }^{\mathrm{z}}\end{array}$ & $\begin{array}{c}\text { Shoot dry } \\
\text { weight }(\mathrm{g})\end{array}$ \\
\hline Nonamended & 0 & 4.4 & 6.0 \\
DL & 2.4 & 4.4 & 6.9 \\
& 4.7 & 4.2 & 7.1 \\
& 7.1 & 4.4 & 7.0 \\
SS & & & \\
& 2.4 & 4.4 & 6.4 \\
& 4.7 & 4.6 & 7.4 \\
& 7.1 & 4.4 & 7.5
\end{tabular}

Main effects

Amendment

$$
P \text { value }
$$

Rate(amendment)

$0.7934 \quad 0.0064$

${ }^{\text {zRoots growing along the container-root ball }}$ interface rated on a scale from 0 to 5 where $0=$ no roots present and $5=100 \%$ of the container-root ball interface covered by healthy white roots.

controls than those amended with DL or SS. Higher foliar $\mathrm{N}$ in nonamended controls might be a function of $\mathrm{pH}$. Sunflower foliar $\mathrm{N}$ was negatively correlated to substrate $\mathrm{pH}$ $(\mathrm{R}=-0.5317, P=0.0010$, data not shown). The fertilizer source used in this experiment was $20 \% \mathrm{~N}$, with $8 \%$ ammoniacal-N and $12 \%$ nitrate-N. Nitrification occurs more rapidly as the substrate $\mathrm{pH}$ increases. Ogden et al. (1987) attributed the increased nitrification response to greater activity of nitrifying bacteria in higher $\mathrm{pH}$ substrates, and Niemiera and Wright (1986) demonstrated that the nitrifying bacteria were largely responsible for loss of ammonium in container substrates with lime-induced high $\mathrm{pH}$. Higher nitrification in high $\mathrm{pH}$ substrates could have rendered less $\mathrm{N}$ available to sunflower roots, especially early in the experiment before roots had grown throughout the substrate. Despite minor differences in foliar $\mathrm{N}$, all plants were within the recommended range (rounded to whole percent). Similar to foliar N, foliar $\mathrm{Ca}$ concentrations were affected by amendment type, but not rates within an amendment. Foliar Ca was highest among plants amended with SS (2.64\%), lower among those amended with DL $(2.38 \%)$, and lowest in nonamended controls $(2.02 \%)$. Foliar $\mathrm{Mg}$ was also lowest in nonamended controls, but higher in DLamended plants than SS-amended plants. The DL used in this trial was composed of $21 \% \mathrm{Ca}$ and $12 \% \mathrm{Mg}$, with a $\mathrm{Ca}: \mathrm{Mg}$ ratio of $1.75: 1$, whereas the SS contained $25 \% \mathrm{Ca}$ and $4.6 \%$ $\mathrm{Mg}$ for a higher $\mathrm{Ca}: \mathrm{Mg}$ ratio of 5.4:1. Soilless substrates comprised primarily of peatmoss have low concentrations of available $\mathrm{Ca}$ and $\mathrm{Mg}$ (Landis, 1990), thus DL is generally the preferred form of liming agent because of its lower Ca: $\mathrm{Mg}$ ratio. The ideal $\mathrm{Ca}: \mathrm{Mg}$ ratio for root growth in soilless substrates is in the range of 1.5 to 4 (Handreck and Black, 2002). Despite differences between amendment type, foliar $\mathrm{Mg}$ concentrations for all treatments were within the recommended range (Whipker et al., 1998). Foliar Mn was affected by amendment type and rate $(P<0.0001)$. Foliar $\mathrm{Mn}$ was lowest in plants growing in DLamended substrates and highest in substrates amended with SS. All plants in DL-amended substrates had similar foliar Mn regardless of rate, whereas plants in SS-amended substrate had increasing foliar Mn with increasing SS rate. The SS used in this research contained $2.2 \% \mathrm{Mn}$, mostly in the form of $\mathrm{MnO}$. There were no treatment differences with respect to foliar $\mathrm{Fe}$ concentration. This is surprising considering the SS contained $20.3 \% \mathrm{Fe}$ in the form of ferrous oxide ( $\mathrm{FeO})$. $\mathrm{FeO}$ contains the divalent form of $\mathrm{Fe}$, which is water-soluble and readily available to plants. However, exposure of $\mathrm{FeO}$ to well-aerated soilless substrates can cause oxidation to the trivalent form which is insoluble in water thus not available for plant uptake. Foliar $\mathrm{Cu}$ levels were slightly depressed in plants growing in DL-amended substrates compared with SS or nonamended substrates. Plants growing in nonamended substrates had the highest foliar $\mathrm{Cu}$ concentrations.

Expt. 2. The primary goal of this experiment was to determine the effect of higher SS rates on substrate $\mathrm{EC}$ and $\mathrm{pH}$ levels, as rates used in Expt.1 were too low to observe the maximum attainable $\mathrm{pH}$ with SS. Because potted sunflowers had minimal effect on substrate $\mathrm{pH}$ in Expt. 1, only fallow containers were used in this experiment. Repeated measures showed a significant time by treatment interaction for substrate EC $(P=$ $0.0025)$. There were no differences among treatments 1 or 2 WAP (Table 5). At 4 WAP, control substrates had the lowest EC levels with $2.2 \mathrm{mS} \cdot \mathrm{cm}^{-1}$, while containers with DL or SS amendment had similar EC with an average of $2.7 \mathrm{mS} \cdot \mathrm{cm}^{-1}$. By $8 \mathrm{WAP}$, amendment type and rate affected substrate EC, however, there was no discernible pattern with respect to increasing rates. Unlike fallow containers in Expt. 1 where EC increased up to 4 WAP and then decreased slightly, EC levels in each treatment in Expt. 2 increased to their highest level at 8 WAP. With continuous fertigation in fallow containers, gradual increase in EC would be expected. Despite increased EC through 8 WAP, levels were within or just slightly higher than the recommended range ( 1.0 to $\left.4.6 \mathrm{mS} \cdot \mathrm{cm}^{-1}\right)$ for floriculture crops (Cavins et al., 2000).

Repeated measures indicated a significant interaction between time and amendment rate $(P<0.0001)$ on substrate $\mathrm{pH}$. Similar to Expt. 1 , at each date substrate $\mathrm{pH}$ was affected by amendment type and rate (Table 6). While repeated measures indicated significant $\mathrm{pH}$ change over time, the magnitude of change was relatively small. The greatest change from the initial $\mathrm{pH}$ measurement at $1 \mathrm{WAP}$ was $0.47 \mathrm{pH}$ units that occurred $8 \mathrm{WAP}$ with the $4.7 \mathrm{~kg} \cdot \mathrm{m}^{-3} \mathrm{DL}$ rate.

Substrate $\mathrm{pH}$ in DL-amended containers increased from 4.6 up to 6.7 at the highest amendment rate 1 WAP (Table 6). According to the fitted parameters of the exponential curve, the extrapolated maximum $\mathrm{pH}$ for $\mathrm{DL}$ at 1 WAP would be 6.6 (Fig. 3). By 8 WAP, substrate $\mathrm{pH}$ in the DL-amended substrates ranged from 4.6 to 6.9 , with an extrapolated maximum $\mathrm{pH}$ of 6.9 (Fig. 3). This maximum extrapolated $\mathrm{pH}$ is higher than that observed for fallow containers in Expt. 1 which had a maximum extrapolated $\mathrm{pH}$ of 6.4.

Substrate $\mathrm{pH}$ in SS-amended substrates ranged from 4.5 to 8.0 at 1 WAP (Table 6 ). Extrapolated along its presumed exponential curve, SS had the potential to raise $\mathrm{pH}$ to a maximum of 8.6 (Fig. 3). By 8 WAP, substrate $\mathrm{pH}$ in $\mathrm{SS}$-amended substrates 
Table 4. Foliar nutrient concentrations in sunflower (Helianthus annuus 'Pacino Gold') growing in 85 peatmoss : 15 perlite substrate amended with dolomitic lime (DL) or steel slag (SS) at three rates, Expt. $1(n=5)$.

\begin{tabular}{|c|c|c|c|c|c|c|c|c|c|c|c|c|}
\hline \multirow[b]{2}{*}{ Amendment } & \multirow[b]{2}{*}{ Rate $\left(\mathrm{kg} \cdot \mathrm{m}^{-3}\right)$} & $\mathrm{N}$ & $\mathrm{P}$ & $\mathrm{K}$ & $\mathrm{Ca}$ & $\mathrm{Mg}$ & $\mathrm{S}$ & $\mathrm{B}$ & $\mathrm{Fe}$ & $\mathrm{Mn}$ & $\mathrm{Cu}$ & $\mathrm{Zn}$ \\
\hline & & \multicolumn{6}{|c|}{---------------------------------------" \%0-------------------------------------- } & \multicolumn{5}{|c|}{ 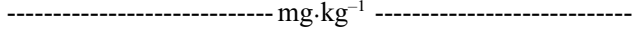 } \\
\hline Nonamended & 0 & 5.61 & 0.74 & 3.70 & 2.02 & 0.61 & 0.68 & 80.8 & 144.3 & 72.7 & 11.5 & 86.5 \\
\hline \multirow{3}{*}{ DL } & 2.4 & 5.35 & 0.75 & 3.52 & 2.35 & 0.88 & 0.67 & 78.0 & 138.7 & 50.6 & 6.5 & 81.2 \\
\hline & 4.7 & 4.93 & 0.67 & 3.38 & 2.34 & 0.99 & 0.69 & 75.8 & 133.3 & 48.4 & 5.5 & 89.3 \\
\hline & 7.1 & 5.13 & 0.69 & 3.47 & 2.46 & 1.00 & 0.68 & 75.3 & 124.8 & 52.7 & 6.3 & 90.3 \\
\hline \multirow[t]{3}{*}{ SS } & 2.4 & 5.26 & 0.68 & 3.52 & 2.47 & 0.71 & 0.69 & 79.7 & 118.7 & 85.6 & 9.6 & 88.2 \\
\hline & 4.7 & 5.07 & 0.70 & 3.43 & 2.69 & 0.78 & 0.65 & 80.2 & 154.3 & 105.6 & 8.3 & 84.7 \\
\hline & 7.1 & 4.94 & 0.75 & 3.54 & 2.75 & 0.87 & 0.64 & 89.9 & 143.3 & 246.9 & 6.9 & 90.4 \\
\hline $\mathrm{LSD}_{0.05}$ & & 0.42 & NS & NS & 0.26 & 0.14 & NS & NS & NS & 13.7 & 1.9 & NS \\
\hline \multicolumn{2}{|l|}{ Recommended range $^{z}$} & $5-6$ & $0.7-0.8$ & $5.4-6.3$ & $2.2-2.5$ & $0.6-0.8$ & NA & $43-53$ & NA & $67-99$ & $6.7-7.2$ & $77-115$ \\
\hline \multicolumn{2}{|l|}{ Contrast analysis } & \multicolumn{11}{|c|}{$P$ value } \\
\hline DL vs. nonamended & & 0.0093 & 0.3618 & 0.0427 & 0.0015 & 0.0001 & 0.8819 & 0.3218 & 0.2789 & 0.0004 & 0.0001 & 0.9230 \\
\hline SS vs. nonamended & & 0.0047 & 0.4979 & 0.0891 & 0.0001 & 0.0036 & 0.3454 & 0.6246 & 0.6173 & 0.0001 & 0.0001 & 0.7847 \\
\hline DL vs. SS & & 0.6992 & 0.7365 & 0.6123 & 0.0015 & 0.0001 & 0.1278 & 0.0424 & 0.4042 & 0.0001 & 0.0003 & 0.8028 \\
\hline
\end{tabular}

${ }^{\mathrm{z}}$ Recommended foliar nutrient concentrations for potted sunflowers (Whipker et al., 1998).

NS = nonsignificant; NA $=$ not available.

Table 5. Electrical conductivity in a $85: 15$ peatmoss: perlite substrate, without plants, amended with four rates of either dolomitic lime (DL) or a steel slag (SS), Expt. $2(n=6)$.

\begin{tabular}{|c|c|c|c|c|c|}
\hline & Rate & $1 \mathrm{WAP}^{\mathrm{z}}$ & $2 \mathrm{WAP}$ & 4 WAP & $8 \mathrm{WAP}$ \\
\hline Amendment & $\left(\mathrm{kg} \cdot \mathrm{m}^{-3}\right)$ & - & - & . & \\
\hline Control & 0 & 1.4 & 1.7 & 2.2 & 4.3 \\
\hline \multirow[t]{4}{*}{ DL } & 2.4 & 1.5 & 1.9 & 2.5 & 4.5 \\
\hline & 4.7 & 1.5 & 1.7 & 2.7 & 3.8 \\
\hline & 9.5 & 1.6 & 1.7 & 2.9 & 3.7 \\
\hline & 14.2 & 1.5 & 1.8 & 2.8 & 4.1 \\
\hline \multirow[t]{4}{*}{ SS } & 2.4 & 1.5 & 1.7 & 2.5 & 4.6 \\
\hline & 4.7 & 1.4 & 1.7 & 2.6 & 4.1 \\
\hline & 9.5 & 1.6 & 1.9 & 2.7 & 4.7 \\
\hline & 14.2 & 1.6 & 1.9 & 2.8 & 4.8 \\
\hline $\mathrm{LSD}_{0.05}$ & & NS & NS & 0.3 & 0.6 \\
\hline \multicolumn{6}{|l|}{ Main effects } \\
\hline Amendment & & 0.3364 & 0.3935 & 0.0004 & 0.0030 \\
\hline Rate(amendment) & & 0.1313 & 0.0347 & 0.2145 & 0.0252 \\
\hline
\end{tabular}

${ }^{\mathrm{z}}$ Weeks after potting (WAP), 6 Mar. 2014.

NS $=$ nonsignificant.

Table 6. Substrate $\mathrm{pH}$ in a $85: 15$ peatmoss: perlite substrate amended with four rates of either dolomitic lime (DL) or a steel slag (SS), Expt. $2(n=6)$.

\begin{tabular}{lcllll}
\hline Amendment & Rate $\left(\mathrm{kg} \cdot \mathrm{m}^{-3}\right)$ & $1 \mathrm{WAP}$ & 2 WAP & 4 WAP & 8 WAP \\
\hline Control & 0 & 4.56 & 4.60 & 4.77 & 4.64 \\
DL & 2.4 & 5.77 & 5.93 & 5.81 & 5.98 \\
& 4.7 & 6.23 & 6.35 & 6.12 & 6.69 \\
& 9.5 & 6.47 & 6.52 & 6.26 & 6.85 \\
& 14.2 & 6.69 & 6.70 & 6.53 & 6.85 \\
SS & 2.4 & 5.85 & 5.88 & 5.67 & 5.64 \\
& 4.7 & 6.47 & 6.52 & 6.27 & 6.56 \\
& 9.5 & 7.67 & 7.64 & 7.50 & 7.64 \\
& 14.2 & 8.04 & 7.96 & 7.85 & 7.87 \\
LSD & & & & 0.19 & 0.18 \\
Main effects & & 0.19 & 0.18 & & 0.0001 \\
Amendment & & & & & 0.0001 \\
Rate(amendment) & & 0.0001 & 0.0001 & 0.0001 & \\
\hline
\end{tabular}

${ }^{2}$ Weeks after potting (WAP), 6 Mar. 2014.

ranged from 4.6 to 7.9 with an extrapolated maximum of 8.4 .

In summary, sunflower grew well in substrates amended with DL or SS at rates up to $7.1 \mathrm{~kg} \cdot \mathrm{m}^{-3}$. Dole and Wilkins (1999) recom- mend substrate $\mathrm{pH}$ for sunflowers between 6.0 and 6.5 , with potential Fe deficiency above $\mathrm{pH} 6.8$ and Fe toxicity below $\mathrm{pH}$ 5.5. Sunflower in this experiment grew well in a substrate $\mathrm{pH}$ ranging from 4.6 (nona- mended control) to 6.7 (SS at $7.1 \mathrm{~kg} \cdot \mathrm{m}^{-3}$ ) with no apparent Fe toxicity or deficiency at these extremes. Foliar Fe concentrations did not respond to substrate treatment (Table 3) and the resultant wide range of substrate $\mathrm{pH}$ and high $\mathrm{Fe}$ content of the SS. In conjunction with a complete and balanced fertilizer, additions of SS or DL do not adversely affect the growth or foliar nutrition of sunflowers. Sunflower caused a significant, albeit small, decrease in substrate $\mathrm{pH}$ with both amendments. Johnson et al. (2013) demonstrated that some species have a greater effect on substrate $\mathrm{pH}$ than others.

$\mathrm{SS}$ had a far greater impact on substrate $\mathrm{pH}$ than DL at rates higher than $4.7 \mathrm{~kg} \cdot \mathrm{m}^{-3}$. This was surprising considering the DL used in this trial had greater CCE than the SS $(103 \% \mathrm{v}$. $73 \%$, respectively). Another factor that affects the neutralizing power of a liming agent is particle size. Some states incorporate particle size of the lime material into the CCE calculation, to determine what is often referred to as "effective calcium carbonate equivalency." In this trial, the DL had finer particle size distribution than the SS and thus should have been more reactive, but was not. The primary liming agent is $\mathrm{CaO}$ in $\mathrm{SS}$, and $\mathrm{CaCO}_{3}$ in $\mathrm{DL}$. The SS used in this experiment contained $34.8 \% \mathrm{CaO}$, and while SS vary from source to source, they are all similar in their high $\mathrm{CaO}$ content which is usually greater than $35 \%$ (Yildirim and Prezzi, 2011). $\mathrm{CaO}$ in $\mathrm{SS}$ is over 100 times more water-soluble than the $\mathrm{CaCO}_{3}$ in DL [0.19 vs. $0.0013 \mathrm{~g} / 100 \mathrm{~mL}$ in water at $25{ }^{\circ} \mathrm{C}$ (Aylward and Findlay, 1999)]. The greater solubility of $\mathrm{CaO}$ allows for quicker reaction in soilless substrates. Over a longer period of time, the higher CCE of DL would ultimately result in a greater $\mathrm{pH}$ reaction (W. Dick, personal communication). However, the short-term $\mathrm{pH}$ reaction is greater for $\mathrm{CaO}$ and more relevant to the 6 - to 8 -week production cycle of most floriculture crops. There was some indication of greater stability from DL amendments in these experiments. In Expt. 2, substrate $\mathrm{pH}$ in DL-amended substrates 

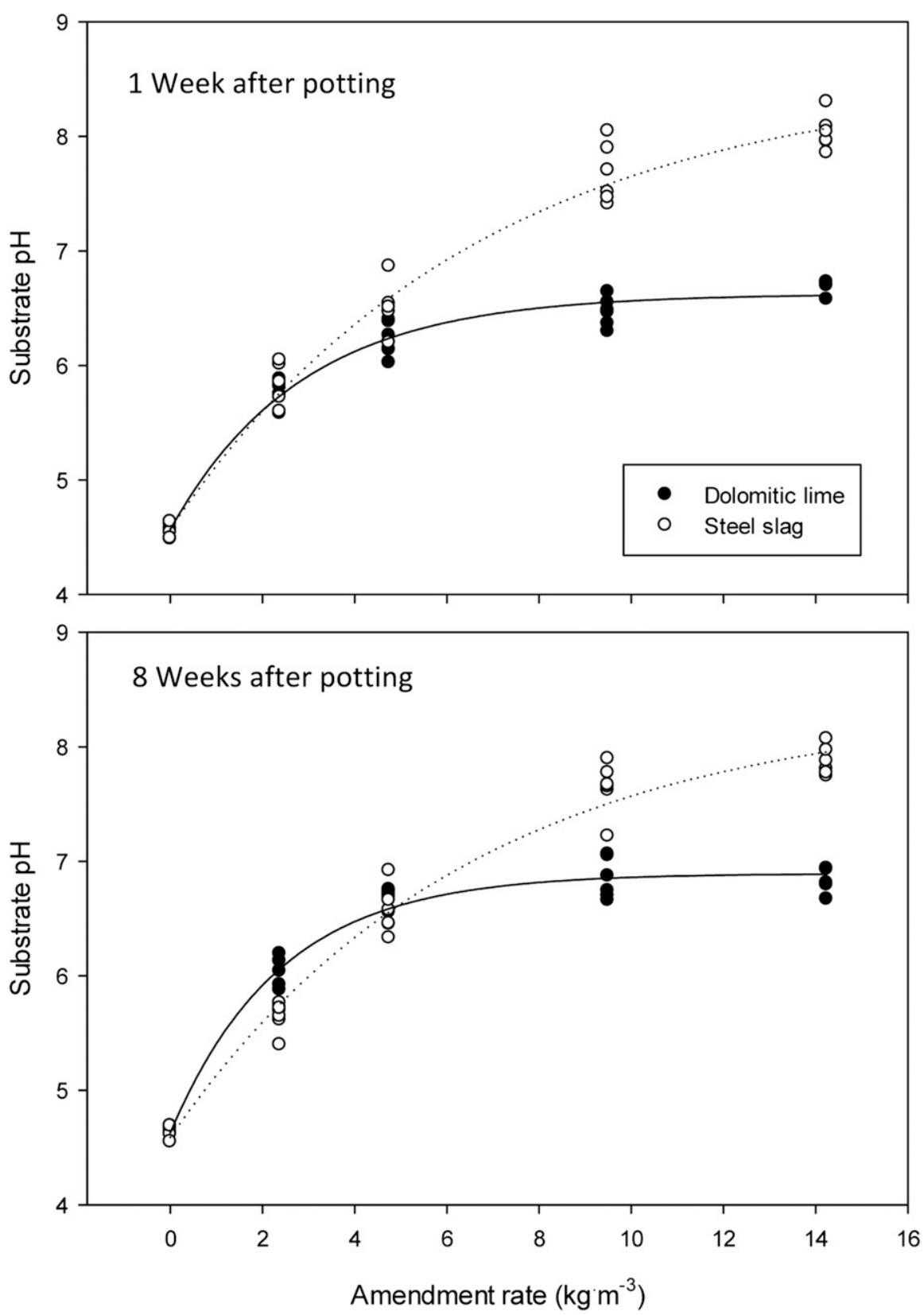

Fig. 3. Relationship between dolomitic lime (DL) or steel slag (SS) rate and substrate $\mathrm{pH}$ at 1 week after potting (WAP) (above) and 8 WAP (below) in a 85 peatmoss : 15 perlite substrate in Expt. 2. There were no plants growing in the containers. Data were fit to the following exponential functions: DL 1 week after potting $\mathrm{pH}=4.57+2.06 *\left(1-\mathrm{e}^{-0.35 *}\right), R^{2}=0.9792$; $\mathrm{SS} 1$ week after potting $\mathrm{pH}=4.58+$ $3.97 *\left(1-\mathrm{e}^{-0.15^{*} \mathrm{x}}\right), R^{2}=0.9790 ;$ DL 8 WAP pH $=4.63+2.27 *\left(1-\mathrm{e}^{-0.42^{*} \mathrm{x}}\right), R^{2}=0.9759 ;$ SS 8 WAP pH $=$ $4.59+3.79 *\left(1-\mathrm{e}^{-0.15 * x}\right), R^{2}=0.9800$.

increased slightly from 1 to 8 WAP, whereas those in SS-amended substrates decreased slightly (Table 6). In Expt. 1, substrate pH declined in both amendments from 1 to 6 WAP, although the decline was greater with SS-amended substrates ( -0.12 vs. $-0.07 \mathrm{pH}$ units for fallow SS and DL amendments, respectively).

The ability to raise substrate $\mathrm{pH}$ is much greater for SS than DL. This might have some application for greenhouse or nursery producers where very high $\mathrm{pH}$ is desired or there is some need to counteract a very acidic or $\mathrm{pH}$-lowering amendment. Most crops are grown at $\mathrm{pH}$ between 5.0 and 6.5 (Cavins et al., 2000), levels that are attainable with DL. Furthermore, over-application of SS could result in exceedingly high $\mathrm{pH}$ whereas even a gross over-application of DL would, according to the results of these experiments, result in $\mathrm{pH}$ no higher than 6.6. Although SS offers more immediate and effective liming power when high $\mathrm{pH}(>7)$ is desired, DL offers an ideal $\mathrm{Ca}: \mathrm{Mg}$ ratio, more moderate $\mathrm{pH}$ increases, and less risk of high $\mathrm{pH}$ with accidental overapplication.

Ali, M.T. and S.H. Shahram. 2007. Converter slag as a neutralizing agent in the amelioration

\section{Literature Cited}

of acidic soils. Intl. J. Agr. Biol. 9:715720.

Altland, J.E. and M.G. Buamscha. 2008. Nutrient availability in Douglas fir bark in response to substrate pH. HortScience 43:478-483.

Andrews, P.H. and P.A. Hammer. 2006. Response of zonal and ivy geraniums to root medium $\mathrm{pH}$. HortScience 41:1351-1355.

Argo, W.R. and P.R. Fisher. 2002. Understanding $\mathrm{pH}$ management in container-grown crops. Meister Pub. Co., Willoughby, OH.

Aylward, G. and T. Findlay. 1999. SI chemical data book. 4th ed. WileyAustralia, Stafford, BC.

Bateman, D.F. 1962. Relation of soil pH to development of poinsettia root rot. Phytopathology 52:559-566.

Cavins, T.J., B.E. Whipker, W.C. Fonteno, B. Harden, I. McCall, and J.L. Gibson. 2000 Monitoring and managing $\mathrm{pH}$ and $\mathrm{EC}$ using the pourthru extraction method. Hort. Info. Lflt 590, NC State Univ.

Dole, J.M. and H.F. Wilkins. 1999. Floriculture principles and species, p. 364-367. Prentice Hall, Upper Saddle River, NJ.

Handreck, K. and N. Black. 2002. Growing media for ornamental plants and turf. Univ. New South Wales Ltd., Sydney, Australia.

Johnson, C.N., P.R. Fisher, J. Huang, T.H. Yeager, T.A. Obreza, R.P. Vetanovetz, W.R. Argo, and A.J. Bishko. 2013. Effect of fertilizer potential acidity and nitrogen form on the $\mathrm{pH}$ response in a peat-based substrate with three floricultural species. Sci. Hort. 162:135-143.

Landis, T.D. 1990. Containers and growing media, vol. 2, the container tree nursery manual. Agr. Handbk. 674. US Dept. Agric., Washington, DC.

Marschner, H., V. Römheld, and M. Kissel. 1986. Different strategies in higher plants in mobilization and uptake of iron. J. Plant Nutr. 9:695-713.

Mayfield, J.L., J.L. Sibley, E.H. Simonne, and D.J. Eakes. 2002. Effect of liming materials on media $\mathrm{pH}$ and overall growth and nutrition of dwarf nandina. J. Plant Nutr. 25:1377-1387.

Mills, H.A. and J.B. Jones. 1996. Plant analysis handbook II. MicroMacro Publishing. Athens, GA.

Niemiera, A.X. and R.D. Wright. 1986. Effect of liming rate on nitrification in a pine bark medium. J. Amer. Soc. Hort. Sci. 111:713-715.

Ogden, R.J., F.A. Pokorny, H.A. Mills, and M.G. Dunavent. 1987. Elemental status of pine bark based potting media. Hort. Rev. 9:103-131.

Peters, J.B., K.A. Kelling, and E.E. Schulte. 1996. Choosing between liming materials. Univ. Wisc. Ext. Pub. A3671.

Raviv, M. and J.H. Lieth. 2008. Soilless culture, theory and practice. Elsevier, London, UK.

Rodriguez, M., F.A. Lopez, M. Pinto, N. Balcazar, and G. Besga. 1994. Basic Linz-Donawitz slag as a neutralizing agent for pastureland. Agron. J. 86:904-909.

Schabenberger, O. and F.J. Pierce. 2002. Contemporary statistical models for the plant and soil sciences. CRC Press, Boca Raton, FL.

Smith, B.R., P.R. Fisher, and W.R. Argo. 2004. Growth and pigment content of containergrown impatiens and petunia in relation to root substrate $\mathrm{pH}$ and applied micronutrient concentration. HortScience 39:1421-1425.

Whipker, B., S. Dasoju, and I. McCall. 1998. Guide to successful pot sunflower production. North Carolina State Univ. Hort. Info. Lflt. 562.

Wright, R.D. 1986. The pour-through nutrient extraction procedure. HortScience 21:227-229.

Yildirim, I.Z. and M. Prezzi. 2011. Chemical, mineralogical, and morphological properties of steel slag. Adv. Civ. Eng. 1:1-13. 